\title{
OVARYAL GEBELIKK OLGUSU
}

\author{
A CASE OF OVARİAN ECTOPIC PREGNANCY
}

\section{Hakan YETIMMALAR \\ Burcu KASAP \\ Külal ÇUKUROVA \\ Adnan KEKLİK \\ Aşkın YILDIZ}

\section{ÖZET}

Bu olgu sununumdaki amacımız çok nadir görülen ovaryal gebelik olgusunu tartışmaktır. Kliniğimizde 2005-2011 yılları arasında sadece tek overyal gebelik olgusu tesbit edilmiştir. Olgumuz 22 yaşında, 2 çocuklu olup karın ağrısı ile başvurmuştur. Overe kama rezeksiyonu yapılarak ovarian ektopik gebelik tanısı intraoperatif ve histopatolojik değerlendirme ile doğrulanmıştır. Bu olgunun klinik bulguları ve semptomları diğer herhangi bir ektopik gebelik olgusuna benzememektedir.

Anahtar Sözcükler: Ektopik gebelik, ovaryal gebelik, rahimiçi araç

\section{SUMMARY}

Our aim is to discuss an uncommon ovarian pregnancy case. There had been only one case of ovarian ectopic pregnancy case between 2005 2011 at our Department. Our case was a 22 years old woman with multiparity and admitted with abdominal pain. Her clinical diagnosis was ectopic pregnancy. Ovarian wedge resection was performed and the diagnosis of ovarian ectopic pregnancy was confirmed intraoperatively and histopathologically. All clinical signs and symptoms of this case resemble to any of ectopic pregnancy case.

Key words: Ovarian Ecopic Pregnancy, Ectopic Pregnancy, Intrauterine Device 


\section{OLGU}

1. 22 yaşında Gravida 2 Para 1 olan hasta (A.G., ev hanımı) alt karın ağrısı, 1 haftalık adet gecikmesi sonrası 7 gündür devam eden vajinal kanama yakınması ile acil servise başvurdu. Hastada 20 aydır T şeklinde bakır rahimiçi araç bulunmaktaydı. Karın muayenesinde sağ alt kadranda ribaund bulgusu olan hastanın transvajinal ultrasonunda sağ paraovaryal bölgede ve Douglasta serbest siv1 tesbit edildi. Beta HCG sonucu 1375,4 mU/mL olan hastanın 9 saat önceki hematokrit değeri \%31,9; 4 saat önceki değer, \%30,7 idi. Yapılan laparatomide peritoneal boşluğunda yaklaşı $200 \mathrm{ml}$ kan tesbit edildi. Uterus, tüpler ve sol over normal görünümde idi. Sağ overde yaklaşık $1 x 1 \mathrm{~cm}$ 'lik rüptür ile kanama odağ kama rezeksiyon ve tamir yapıld1. Hastada postoperatif dönemde dramatik düzelme izlendi. Patolojik değerlendirme ovaryal gebelikle uyumlu idi (patoloji prot: 910440 A ve B): ovaryal doku, kan pihtıları, koryonik villus ve korpus luteum tesbit edildi. Hastaya intraoperatif 2 ünite eritrosit süspansiyonu ve 1 ünite taze donmuş plazma transfüzyonu yapıldı. Operasyon sonrası 3.günde evine gönderilen hastanın yapilan haftalık Beta HCG izlemlerinde azalma ve sonunda negatifleşme tesbit edildi. Ovaryal ektopik gebelik oldukça nadir rastlanılan ayrıca rüptür sonrası oluşabilecek komplikasyon oranı diğer ektopik gebeliklerden daha yüksek, semptom ve bulguları ise herhangi bir ektopik gebelik olgusuna benzeyen bir hastalıktır.

\section{TARTISSMA}

Ovaryal gebelikler ektopik gebeliklerin \% 1 ila 6'sin oluşturmaktadır. Ovaryal gebeliklerin belirgin klinik bulguları yoktur. Karın ağrısı, düzensiz vajinal kanama ve baygınlık hissi gibi bulgular diğer ektopik gebeliklerle benzerlik gösterir ve ovaryal gebelikleri tubal gebeliklerden ayırt edecek belirgin klinik, laboratuvar test ve ultrason bulgusu yoktur. Ovaryal gebeliklerin kesin tanısı için 1878 yılında Spielberg tarafindan geleneksel kriterler öne sürülmüştür. Bunlar içinde etkilenen tarafta sağlam tuba, fetal kesenin over pozisyonunu etkileyecek şekilde yer kaplaması, ovaryal ligamanla overin uterusa bağlı olması ve histopatolojik olarak overyal dokuda fetal eklerin tespiti gibi (3). Hastamızın bulguları bu ölçütlere uymaktadır. Histolojik bulgu tanının konulmasında kesin yöntemdir. Ovaryal gebeliğin gelişme nedenleri ILETişim

Atatürk Eğit. ve Araş. Hast., 3. Kadın Hastalık. ve Doğum Klin., İzmir Dr. Burcu Kasap

Tel: 02322431530

Cep Tel: 5052711056 belirsiz kalmaya devam etmektedir (4). Hipotezler, rüptüre folikülden oositin salınamaması, disfonksiyonel tubalar, tunika albugineanın inflamatuar kalınlaşması ve güncel veriler intrauterin araca bağlı olabildiği yönündedir (4). Bir antite de boş folikül sendromudur. Yardımcı üreme teknikleriyle normal gelişim gösteren folikül ve östrojen seviyelerine rağmen olgun ovarian folikülden oosit elde edilememesi, tekrarlayan oosit aspirasyonları da ovarian gebelik nedeni olabilir (6). Semptom ve bulgular tubal ektopik gebelik ile benzerlik gösterir. Ayırıcı tanıda dikkate alınması gereken durumlar rüptüre hemorajik korpus luteum ve endometrioma ve tubal ektopik gebeliktir (4). Gebeliğin ilk 3 ayda rüptüre olması genel kuraldır fakat literatürde ilerlemiş hatta sonuca ulaşan gebelik olguları da bildirilmiştir (3). Tubal ektopik gebeliğin \%15 tekrarlama olasılığına karşın tekrarlayan ovaryal gebelik bildirilmemiştir (7). Ultrasonografik beceri ve gelişimlerle tanıyı preoperatif koymak mümkündür (4). Tedavi prokolü tek doz metotreksat veya konsevatif cerrahiyi içermektedir. Laparotomi veya laparoskopik parsiyel ooferektomi siklıkla tercih edilen yöntemdir (6). Ovaryal gebelik sonrasında fertilite değişmemektedir (5). Bakır içeren rahim içi araçların kullanımı arttıkça ovaryal gebelik de artmaktadır.

\section{KAYNAKLAR}

1. Alkatout I, Stuhlmann-Laeisz C, Mettler L, Jonat W, Schollmeyer T. Organ-preserving management of ovarian pregnancies by laparoscopic approach. 2011 Jun 30;95(8):2467-70.

2. Brandt JS, Musa F, Wang X, Shaktman BD Ovarian pregnancy and a copper intrauterine device. Rev Obstet Gynecol. 2010; 3(3): 81 .

3. Güzel AB, İbrahim, Ürünsak İF, Büyükkurt S, Atay Y, Güleç ÜK. Ovarian pregnancy after intrauterine insemination. J Turk Soc Obstet Gynecol. 2009; 6(3): 216-9

4. Yumru AE, Bozkurt M, Aksoy HE, Advanced Primary Ovarian Pregnancy Misdiagnosed as Bicornuate Uterine Pregnancy: Differential Diagnosis Turkiye Klinikleri J Med Sci 2009; 29(1):288-90

5. Coşar E, Köken GN, Aral İ, Şahin FK, Arı̈z DT, Yılmazer M. Ovarian Ectopic Pregnancy: Case Report. Turkiye Klinikleri J Gynecol Obst 2008;18(2):134-7

6. Qublan H, Tahat Y, Al-Masri A. Primary ovarian pregnancy after the empty follicle syndrome: A case report. J Obstet Gynaecol Res. 2008; 34: 422-4.

7. Sergent F, Mauger-Tinlot F, Gravier A, Verspyck E, Marpeau L. Ovarian pregnancies: Reevaluation of diagnostic criteria. J Gynecol Obstet Biol Reprod. 2002; 31: 741-6. 